\title{
The Size of the Public Economy and Its Economic Efficiency Problem
}

\author{
Mehmet $\operatorname{Nar}^{1}$ \\ ${ }^{1}$ Faculty of Economics and Administrative Sciences, Department of Economics, Artvin Coruh University, Turkey \\ Correspondence: Mehmet Nar, Associate Professor, Faculty of Economics and Administrative Sciences, Department \\ of Economics, Artvin Coruh University, Turkey.
}

Received: September 26, 2020

Accepted: November 17, 2020

Online Published: December 10, 2020

doi:10.5430/rwe.v11n6p234

URL: https://doi.org/10.5430/rwe.v11n6p234

\begin{abstract}
The public economy, which has reached a significant size in terms of both quality and quantity, collects and spends resources between $30 \%$ and $70 \%$ of GDP on average, shapes up the economy, and acts as a complementary element next to the private sector. Therefore in this study, the relationship between the size of the public sector (its spending) and its efficiency was analyzed. For this purpose, a 24-year data of the period, 1995 to 2018, were evaluated. In this context, a comparison was made between the data of 36 OECD-member countries and seven non-OECD countries. In conclusion, it was seen that, since OECD-member countries are generally high-income countries, public expenditures in those countries are far from populism and are used effectively in order to meet the social needs. On the other hand, in developing countries, since the growth in the public expenditures tends towards mostly public goods and services in which political actors are given priority, the efficiency either remains limited or is negative.
\end{abstract}

Keywords: public economy, public spending, efficiency, public duties, efficiency in allocation, efficiency in production

\section{Introduction}

Today, the limited government notion of classical economics gives way to the notion of the modern state whose primary aim is to ensure social welfare. This situation has led to continuous growth in the size of the public economy. Specifically, expenditures for education, health, shelter, and social protection are important within this framework. Additionally, the demands of the public and standards of living, parallel to the increase in the rate of national income, promote expansion of the public sector (Nar \& Nar, 2019). In general, the rate of public expenditures to the GDP was used to calculate the size of the public sector because the rate of total government expenditures to the GDP could be easily obtained at the national level. Furthermore, statistics could be consistently collected and presented over the course of time and among countries. For this reason, the rate of public expenditures to the GDP is always used as a standard method of measurement. The effectiveness of its size is measured and assessed through the concept of efficiency. Moreover, efficiency indicators are achieved by worldwide governance indicators (WGI). The main problem with this practice is the question of whether scarce resources are spent in accordance with the efficiency criteria, that is, social priorities.

In developed countries where the level of national income is high and the role of the state in the economy is significant, the size of the public sector and its efficiency level are also high. Since an increase in the expenditures tends towards the production of the goods and services to which the society gives a priority, efficiency grows apace. On the other hand, in developing countries, because an increase in the size of public expenditures is mostly directed to the notion of public goods and services generally taken into account according to the priorities of political actors, the efficiency rate in this situation either remains limited or shows a negative tendency.

In this study focused on OECD-member countries and non-OECD, the size of public expenditures was compared with the efficiency levels, and, in accordance with this purpose, an index study was carried out. When it was considered that the OECD-member countries included in the study were generally ones with high levels of income, it was clear that the public expenditures of those countries were far from populism and was conducted to meet social needs. Even though the size index value of the public volumes of non-OECD countries were lower than that of the OECD members countries in nine out of the 24 years examined, it was concluded that their efficiency index values were higher than those of OECD countries. In the relevant period between 2004 and 2013, the public volume of non-OECD countries was lower than that of OECD countries but more efficient. 
In this study, the relation between public spending and efficiency levels are evaluated. In other words, this study analysis the contribution of public spending to the social welfare (level of efficiency).

\section{The Scope of Public Economy}

While personal needs are met in the market economy, public needs are satisfied within the scope of the public economy. The raison d'etre of the public economy is to meet public needs. The public economy, which came into existence as an art, a science, and a moral necessity in the historical process, is the focal point of economics (Neuberger, 1971). In the most general sense, the public economy defines the processes related to economic efficiency, distribution, government economic policies, market failure, tax evasion, and the bureaucratic decision-making mechanism. On the other hand, in the strictest sense, it is a field consisting of tax and expenditure policies from the point of the collection of taxes to the making of expenditures (Hindriks \& Myles, 2006).

According to Myles, the public economy is an economic-political field of study which places special emphasis on the tax issue. In this field, so many issues are analyzed including the determination of social security policies. As a discipline, it has a deep-rooted history, and many skilled economists have studied it. For example, Ricardo (1917) discussed the effects of public debt, Cournot (1838) investigated taxation in imperfect competition markets, Edgewort (1925) examined the effects of taxation on companies that produce a large number of products, and Pareto (1909) laid a foundation for a social decision-making mechanism (Nar, 2013).

While the economy is a concept as old as the history of humanity, the public economy is a field of science related to the appearance of states since a state is a separate being with a legal entity apart from the individuals of which it is composed. It is not possible to understand the public economy without understanding the formation of states. The simplest doctrine dealing with the question of where states originated belongs to Aristotle who believed that the formation of the state is one of the natural states of human societies and, hence, there is no need to explain it. However, Jean-Jacques Rousseau said that the formation of states depends on a social contract. He explains that people destroy simple societies because they think their lives will be better when they live in a state system rather than a simple society. A third doctrine asserts that, with the construction of extensive irrigations systems, states began to be formed, and, for this purpose, weak principalities or "beyliks" came together and formed states. The fourth and the most important doctrine is the expansion of population density; specifically, population increase caused the formation of complex societies, that is, states.

Thus, certain ways of thinking contributed to the formation of states. Those are: (i) societies can protect themselves against internal and external attacks by concentrating power under a single control, (ii) societies need the centralization in order make effective decisions, and (iii), although the transfer of goods related to economic concerns had previously been based on the exchange mechanism, in complex societies, economic functions can be fulfilled effectively by having new distribution policies (Diamond, 1999).

Thus, the primary duty and function of the state (public economy) in traditional societies is fundamentally the production of public goods and services for internal and external security. To do this, there is need for not only a strong army but also a continuous taxation structure to keep up the system. The tools of military power are taken from the hands of single individuals and centralized. In the same way, the taxes collected from the assets of the citizens are combined in the hands of the centralized government. In this way, financial means collected in the centralized government support the monopoly of coercive power, and the latter maintains a monopoly on taxation. On the other hand, neither of these two is privileged over the other. The economy monopoly does not have privilege over the military, nor is the military privileged over the economy (Elias, 2002).

Consequently, this analysis shows us that the relationship between the production of public goods and services and taxation policies, namely "the public economy," began with the birth of states and continued to increase in the historical perspective.

\section{Development of the Public Economy}

The public economy, which focused on security policies in traditional (agricultural) societies, has reached a significant size in modern industrial and our current information societies. In modern societies, the state is a structure that attaches importance not only to internal and external security but also to infrastructures and superstructures to ensure the existence of social welfare with its structures that change and transform over time, looks out for the public interest at the point of decision-making and the application of the decisions taken, and, when required, functions in accordance with commercial principles in field of economics alongside the production of public goods. This is a process extending from a "foundation economy" involving many services like education and health which the king or emperor offers to the people he regards as his subjects as a sign of favor to a "public economy" based on citizens 
in a modern society.

In terms of quantity and quality, the level that the public economy has reached today is a consequence of different concepts regarding the notion of the state. The public economy has taken shape and developed within the framework of those different concepts (Öztürk, 2020). In the mercantilist state, understanding wealth requires a strong state, a strong army, and a strong treasury and so supports a diverse public sector. According to physiocracy, the source of wealth is not money, but agriculture; it is the natural order that exists in nature. Since state intervention would disturb this order, the public economy should be limited. The Wealth of the Nations published in 1776 by Adam Smith is the starting point for classical economics, a philosophy that asserts that the state should provide only services such as diplomacy, justice, and defense which the private sector cannot provide. Since markets are regulated by the invisible hand (prices), the public economy should be also limited. However, the Great Depression in 1929 and the resulting deflation and unemployment problems indicated the inadequacy of classical economic analysis. For this reason, there is a need for the visible hand of the state rather than the invisible hand of the market. This need brings into play a Keynesian economic understanding to the agenda which envisages the intervention of the state in the economy by increasing public expenditures. Consequently, this situation leads to the emergence of the notion of the social welfare state (fiscal policy). Since the duties of the state increase in Keynesian economic policies, the sphere of activity of the public economy grows as much as possible (Bilgili, 2009; Kalenderoğlu, 2013; Musgrave, 2006; Screpanti \& Zamagni, 2005).

In 1974, the world oil crisis made the concept of stagflation, a situation in which both unemployment and inflation problems existed together, a current issue. Since Keynesian policies could not explain the concept of stagflation, neoliberal policies came into view, starting with supply-siders and monetarist economists. According to economists who adopt supply-side economics, the basic problems in the stagflation situation are inflation and unemployment, which is why it is possible to fight both unemployment and inflation by increasing production. Therefore, it is necessary to focus on the public sector and decrease public expenditures and taxes, minimize the state, and limit the public economy. On the other hand, monetarists explain the primary problem in stagflation as the coining of money on a complimentary basis. The solution to this problem is to increase the money supply in parallel with economic growth. Since the main factor influencing the economy is money, the sphere of activity of the public economy should be restricted as far as possible. According to rational expectations theory, individuals are rational and behave rationally. Since the expectations are rational, the decisions taken in the economy are inevitably rational. The public economy should be also restricted because there is no need for state intervention in the economy. Other neoliberal approaches, such as the Austrian economic school's constitutional economics and public choice analysis, also argue that the public sector should be limited. However, in reality, according to the neo-classical school, there may be deviations from the conditions of perfect competition. Because of some factors such as externalities, imperfect markets (monopolist, oligopoly, natural monopoly), public goods, and limited access to information, market failure might become a problem. As long as externalities and public goods exist, the public economy will inevitably exist (Musgrave, 2006; O’Neill, 2001; Screpanti \& Zamagni, 2005).

Judgements related to the size of the public economy also summarize the development of the public sector. Adolph Wagner (1880) says that the increasing national income in developed countries constantly expands the size of the public economy. According to Peacock \& Wiseman, wars and national crises lead to spikes in public expenditures, but even when the crises come to an end, the expenditures continue to increase. H. C. Adams (1898) says that public expenditures continue to increase, not only in an absolute but in a relative way, and this increase is, so to speak, a general law for developed countries. Moreover, according to F. Nitti, military expenditures are the reason for the public expenditures. Rostoy argues that not only financial activities but also non-financial activities cause an increase in public expenditures. Additionally, according to Pigo \& Dalton, the expenditures for social welfare is the most important reason for public expenditures. Baurnol thinks that, since the public sector attaches priority to labor-intensive manufacturing, cost and expenditures will necessarily increase. In addition, according to Musgrave (1959), except for expenditures related to war, the increase in the expenditures for education, health, and social needs is the reason behind the expansion in the public sector. In brief, the economic tasks of the state-allocation, distribution, and stability-determine the size of this expansion.

Allocation is the distribution of resources among the private and public goods in order to support the production of private and public goods efficiently in an economy. It is actually the allocation of the resources for the optimal supply of the public goods to be described as social goods. Distribution is the division of income and wealth fairly among members of the society. On the other hand, income distribution valid in terms of the market is not very fair because the distribution in question is related to the share that individuals take from the production factors they have. If a person has a production factor (such as labor) but cannot put it into production or s/he cannot work because of 
unemployment, if s/he is disabled, elderly, or in bad health, s/he cannot take advantage from this factor. In such cases, the state makes secondary income distributions by redistributing the income. With stability, the aim is to make possible "full employment" and "price stability." In a broad sense, employment is the putting of production factors into production. Yet, in the strictest sense, it means the ability of workers to find a job. Certain economic problems like inflation, deflation, and stagflation can be solved with price stability (Brunori,1998; Edizdoğan et al., 2012; Musgrave, 2000; Musgrave, 2006). It is clear that Masgurave's traditional definition of the tasks of the state summarizes the expansion of the public economy. Additionally, the tasks and functions of the state in today's "information societies" evolve, become varied, and take shape in parallel with technological and scientific developments.

The concept of the information society was first used by Robert Lane (1966) who explained it as a production structure in which the rate of growth of knowledge-intensive sectors is high, and its weight in the economy is determinant (Coniglione, 2013). Today, information is not only a primary power source but also a production factor. There is power based on knowledge behind the wealth and productivity of developed countries. Computers, technological devices, nanotechnology, silicon chips, and fiberoptics networks are the products of knowledge (Wentzel, 2011). Industrial production in industrial societies has started to become information production in information or knowledge-based societies. The expenditures for this field (innovation, R \& D, and technology) also expand the size of the public economy.

On the other hand, a significant part of the public economy has transformed to transfer expenditures such as defense, education, health, interest and debt payments, and, in particular, social welfare services such as retirement pensions, unemployment compensation, and old age and disability assistance. The expenditures in question continued to increase around the world. While the increase in expenditures have remained low in the UK and the USA, the highest expenditures have occurred France and Germany (Heer, 2019). Further, it is interesting to compare the social welfare expenditures of the countries of continental Europe and Anglo-Saxon countries. American social ethics allows that it is acceptable not to support the poor, but this is not the case in a typical western European country. Nevertheless, in the same American social morality, it is not possible to tolerate a double-digit unemployment rate, which is quite common in Europe and accepted with considerable tolerance. For this reason, there is a difference between the types of political decisions that are privileged in Europe and the ones which are in force in the USA where of a population of 328 million, 15\% (50 million people) still lives below the poverty line without any kind of health insurance or assistance (see USA Census Bureau, 2019 report). On the other hand, every American government suffers when the unemployment reaching double-digits. Contradiction and difference are much higher in America since, while America can become self-sufficient, this is not the case for Europe. Similarly, social transfers (cash money) are generally applied only to poor people in Australia and England while in countries like France or Germany, social transfers are distributed during the entire life cycle as large amounts of monetary transfers (Heer, 2019; OECD, 2012; Piketty, 2015; Sen, 1997). In addition to these transfers, expenditures by the government to eliminate the negative effects of globalizations, to fight against corruption, and to protect the environment as well as expenditures for the activities of regulatory and supervisory authorities lead to a continuous expansion of the public economy. The size of the public economy shows a difference linked to the social, political, and economic structures of the countries (Nar, 2013).

The size of the public sector in economies is generally measured by the rate of public expenditures to the GDP because the rate of total government expenditures to the GDP can be easily obtained at the national level. Statistics can be consistently collected and presented over the course of time and among countries. Therefore, the rate of public expenditures to the GDP is commonly used as the standard method of measurement. Furthermore, measurement methods such as the rate of public investments to total investments, tax income to the rate of GDP, public debts to the rate of GDP, the number of workers in the public sector to the total number of workers can also be used to measure the size of the public economy (Dewar, 2010; Kwon, 1999).

\section{The Size of the Public Economy and Its Economic Efficiency}

Another concept that comes into view depending upon the size of the public sector is the concept of public efficiency. Efficiency forms from the concepts of (i) efficiency in allocation and (ii) efficiency in production. Efficiency in allocation means the distribution of the resources based on the priorities of the society. Efficiency in production, on the other hand, is cost minimization. Thus, economic efficiency means to present the goods and services prioritized by the society with a minimum cost. Organizational scientist Hick (1927) on the difference between efficiency and productivity says that "while efficiency is to do the right job, productivity is to do the job right." He explains that efficiency in production is actually productivity (Nar, 2013). In welfare economics, 
efficiency is "the criterion of the Pareto efficiency." Since profit maximization is $\mathrm{P}=\mathrm{MC}$ in all kinds of competition conditions, the Pareto efficiency is ensured by increasing resources (production) up to this point (Musgrave \& Musgrave, 2017). Based on that, the reference point for the efficient use of scarce resources in the market economy is the Pareto optimal. The public economy takes advantages from the Pareto criterion in the use of scarce resources and establishes a mutual bond with the welfare economy. However, the primary problem in the practice is revealed at the point of whether the scarce resources are really spent in compliance with efficiency criteria, that is, the priorities of society.

In the literature, one of the main reasons for the expansion of the public sector is that public goods and services are produced at a much higher cost than in the market economy. Moreover, the public sector has an incentive mechanism with regard to the production of more goods and services. The fact that politicians concentrate on production in order to be reelected may lead to inefficiency. According to OECD, having civil servants who are qualified and educated and who have a high level of human capital are the preconditions for efficiency and superior regulations in the public sector. However, in economies where favoritism or clientelism is valid, ideological partisanship is common, and social capital is important, the efficient use of public goods is extremely difficult to achieve. Figure 1 draws attention to this issue and explains the way that public duties (civil servants) are acquired through the concepts of human capital, social capital. and physical capital. According to the OECD (Government Report at a Glance), in the countries where the centralization tendency is high, the concepts of social or physical capital become prominent instead of human capital in the procurement of civil servants. This situation is seen as one of the primary reasons for inefficiency in the public sector. In such countries, while human capital accumulation (education) has a limited function, the concepts of social capital (relatives, ideology, patronage) and physical capital (money and assets) come to the forefront. The circular area in the figure shows the degree of capital intensity, in other words, the presumptive conditions of factor endowments. According to the model, it is necessary to support human capital with social or physical capital in public appointments. Because this situation decreases trust in the public policies and decisions in public opinion, the principle of merit loses its meaning. While misgovernment, supernumerary civil servants, irregular assistance, irregular staff recruitment, and clientelism are accepted as crimes against the public (res publica), it is seen that powerful interest groups continue to have control over the state capitals in all areas (Bernholz \& Vaubel, 2007; Dutu \& Sicari, 2020; Foster, 1997; Nar, 2013).

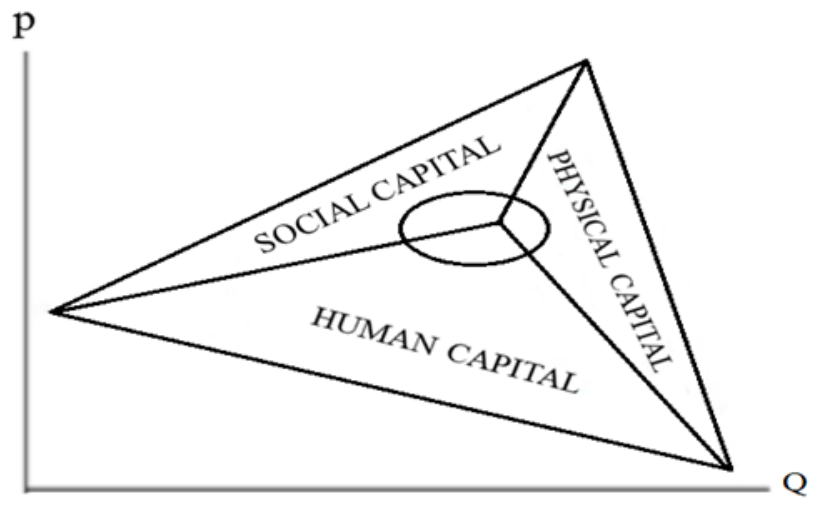

Figure 1. Economic evaluations of public duties

On the other hand, according to the theory called "economic analysis of policy" or "public choice analysis," developed by certain economists like Buchanan and Tullock and founded by Duncan Black in 1948, the actors directing the public policies are the voters, politicians, bureaucrats, and interest groups. According to this theory, the person or groups in question are the people who are trying to maximize their private interests rather than the public interest. Thus, this situation leads to higher service costs, lower service quality, and lower efficiency levels in the public sector. Further, the expenditures of governments for regulatory activities cause inefficiency rather than efficiency in the public economy. It might be said that the expenditures in question take the place of the expenditures of government (Bassam, 2020; Berry \& Lowery 1987; Shughart, 2004). Massive bureaucratic structuring in the public economy is one of the other indicators of inefficient production and the expansion of public sector when compared with the private sector. Another reason for the loss of efficiency in the public economy is the loss of 
freedom. In the private markets, there are production and consumption models resulting from voluntary change, but consumers in the public sector are obligatory buyers of the goods and services produced. According to those who argue for opposing views, the existence of the public economy is compulsory. Especially the expenditures for social welfare, welfare state applications, redistribution policies, policies for macroeconomic stability, and the contributions of these policies to "economic growth" entail the expansion of the public sector. Since the aim of the public economy is to increase social welfare, the inefficiency derived as a result of it is always at a level to be tolerated (Fourie \& Burger, 2010; Greiner \& Fincke, 2009; Hallwood \& MacDonald, 2009; Kosor et al, 2019).

\section{Data Set and Methodology}

Does the growth in the size of public economy or the expansion in the size of the state mean efficiency? To answer this question, a comparison should be made between the size of public expenditures and the efficiency of those expenditures. An index study was conducted to compare between countries. For this purpose, data from 36 OECD member countries and seven non-OECD member countries were evaluated. In this context, as non-OECD member countries, Chad, Algeria, Pakistan, and the BRICS countries (China, India, Russia, Brazil) were examined.

The size of the public sector is measured by the rate of public expenditures to the GDP. Moreover, the efficiency indicators are taken from worldwide governance indicators (WGI), and the governance data is from 214 countries. The concept of governance or "good governance" defines an order in which there is a clear and predictable decision-making process in the society, a professional bureaucratic government, a government responsible for its actions and operations, and a civil society participating actively in the public decision-making process (IMF, 1997; WGI, 2020).

The concept of governance which was first defined by the World Bank consists of the following principles, especially efficiency:

(i) efficiency of the state

(ii) political stability, the absence of violence and terror

(iii) quality of state's regulatory activities

(iv) rule of law

(v) control over corruption

In this way, the level of democratic accountability is measured.

In this study, first, an index study was carried out in order to make a comparison between the level of efficiency of the public expenditures of OECD member countries and non-OECD countries. To improve the index, the "minimum/maximum approach" was employed.

In the first step, the minimum and maximum values in the series were determined for the period of 1995-2018. After that, for every country, an index value was calculated with the help of Formula 1.

$$
\text { Index }=\frac{\left(D_{\max }-D_{i}\right)}{\left(D_{\max }-D_{\min }\right)}
$$

Explanations of expressions in the formula are as follows:

$D_{\text {max }}$ : maximum value of the series

$\mathrm{D}_{\text {min }}$ : minimum value of the series

$\mathrm{D}_{\mathrm{i}}$ : real value.

In the second step, the arithmetic average of the index value calculated for every country was taken, and the sub-index value was determined:

$$
\text { Sub }- \text { index }=\frac{1}{n} \sum_{i=1}^{n} \text { Index }_{i}
$$

In the last step, the sub-index value was taken away from 1, and the index that will make the comparison among country groups possible was formed:

$$
\text { Index }=1-\text { Sub-Index }
$$

All the calculations were made using the MS. Excel 2016 package program. 


\section{Findings}

In the first stage of the research, the maximum and minimum values of the size of the public volume and the efficiency of public expenditures were determined for the period of 1995-2018.

Table 1. Maximum and minimum values of the series

\begin{tabular}{|c|c|c|c|c|c|c|c|c|}
\hline & OECD & & & & Non-C & & & \\
\hline & Size & & Efficie & & Size & & Efficie & \\
\hline & Min & Max & Min & Max & Min & Max & Min & Max \\
\hline 1995 & 13,26 & 63,03 & 55,70 & 99,50 & 12,00 & 38,28 & 13,10 & 54,10 \\
\hline 1996 & 15,47 & 60,97 & 55,70 & 99,50 & 12,00 & 38,28 & 13,10 & 54,10 \\
\hline 1997 & 15,36 & 58,74 & 55,50 & 99,30 & 12,00 & 38,58 & 16,10 & 54,80 \\
\hline 1998 & 17,82 & 56,41 & 46,10 & 99,50 & 13,00 & 40,86 & 19,70 & 55,40 \\
\hline 1999 & 18,13 & 56,03 & 50,30 & 99,40 & 14,90 & 39,57 & 17,60 & 59,90 \\
\hline 2000 & 17,95 & 53,04 & 56,90 & 99,50 & 16,14 & 34,48 & 14,90 & 61,00 \\
\hline 2001 & 19,16 & 52,84 & 58,70 & 100,00 & 15,55 & 36,23 & 18,90 & 60,50 \\
\hline 2002 & 17,93 & 53,63 & 60,70 & 100,00 & 17,88 & 38,95 & 19,90 & 59,70 \\
\hline 2003 & 20,22 & 53,80 & 60,70 & 100,00 & 17,35 & 41,03 & 12,80 & 63,30 \\
\hline 2004 & 20,64 & 53,71 & 57,60 & 100,00 & 13,16 & 38,22 & 8,90 & 58,10 \\
\hline 2005 & 20,88 & 53,29 & 57,40 & 100,00 & 12,00 & 39,81 & 5,90 & 52,90 \\
\hline 2006 & 19,72 & 52,88 & 58,00 & 100,00 & 13,93 & 39,24 & 4,40 & 57,10 \\
\hline 2007 & 20,40 & 52,57 & 58,70 & 99,50 & 17,16 & 37,65 & 2,40 & 59,20 \\
\hline 2008 & 22,85 & 53,30 & 60,70 & 99,50 & 18,80 & 37,95 & 2,40 & 58,70 \\
\hline 2009 & 26,40 & 57,15 & 60,30 & 99,50 & 19,89 & 42,60 & 4,30 & 57,90 \\
\hline 2010 & 25,15 & 65,08 & 60,30 & 99,50 & 20,26 & 39,91 & 4,30 & 57,90 \\
\hline 2011 & 23,30 & 56,43 & 63,50 & 100,00 & 19,16 & 40,12 & 6,70 & 58,00 \\
\hline 2012 & 23,13 & 57,95 & 63,00 & 100,00 & 21,66 & 43,54 & 3,30 & 57,80 \\
\hline 2013 & 22,93 & 62,37 & 63,00 & 100,00 & 21,82 & 37,45 & 7,10 & 55,50 \\
\hline 2014 & 23,78 & 57,28 & 61,50 & 99,50 & 20,11 & 40,61 & 6,30 & 64,90 \\
\hline 2015 & 25,19 & 56,80 & 61,50 & 99,50 & 18,34 & 45,81 & 6,70 & 68,30 \\
\hline 2016 & 25,37 & 56,59 & 54,80 & 99,50 & 14,37 & 41,67 & 6,30 & 66,80 \\
\hline 2017 & 25,37 & 56,33 & 52,40 & 99,50 & 14,88 & 39,21 & 6,30 & 67,80 \\
\hline 2018 & 20,43 & 55,86 & 47,60 & 99,50 & 13,33 & 38,49 & 6,70 & 69,70 \\
\hline
\end{tabular}

After that, by means of Formula 1, the sub-index values were calculated for every country and groups from every country, and, using Formula 2, their arithmetic averages were obtained.

Table 2. Means of sub-indexes

\begin{tabular}{lrlrl}
\hline & OECD & \multicolumn{3}{c}{ Non-OECD } \\
\hline & Size & Efficiency & Size & Efficiency \\
\hline 1995 & 0,3961 & 0,3480 & 0,5196 & 0,4094 \\
\hline 1996 & 0,4011 & 0,3480 & 0,5120 & 0,4094 \\
\hline
\end{tabular}




\begin{tabular}{lllll}
\hline 1997 & 0,3883 & 0,3330 & 0,4984 & 0,4249 \\
\hline 1998 & 0,3807 & 0,2744 & 0,5324 & 0,4646 \\
\hline 1999 & 0,3811 & 0,2919 & 0,5588 & 0,5019 \\
\hline 2000 & 0,3515 & 0,3323 & 0,5383 & 0,5132 \\
\hline 2001 & 0,3496 & 0,3470 & 0,5294 & 0,4643 \\
\hline 2002 & 0,3410 & 0,3487 & 0,5518 & 0,4049 \\
\hline 2003 & 0,3623 & 0,3372 & 0,5859 & 0,3963 \\
\hline 2004 & 0,3938 & 0,3205 & 0,5344 & 0,3412 \\
\hline 2005 & 0,3978 & 0,3405 & 0,5577 & 0,2763 \\
\hline 2006 & 0,3914 & 0,3485 & 0,5660 & 0,3323 \\
\hline 2007 & 0,4019 & 0,3516 & 0,5486 & 0,3365 \\
\hline 2008 & 0,4057 & 0,3635 & 0,4934 & 0,3578 \\
\hline 2009 & 0,3887 & 0,3635 & 0,5173 & 0,3571 \\
\hline 2010 & 0,5062 & 0,3542 & 0,5069 & 0,3417 \\
\hline 2011 & 0,3864 & 0,3960 & 0,5017 & 0,3832 \\
\hline 2012 & 0,4103 & 0,3939 & 0,5804 & 0,3748 \\
\hline 2013 & 0,4703 & 0,3875 & 0,4943 & 0,3657 \\
\hline 2014 & 0,4263 & 0,3549 & 0,5082 & 0,4473 \\
\hline 2015 & 0,4515 & 0,3543 & 0,5435 & 0,4374 \\
\hline 2016 & 0,4716 & 0,3144 & 0,4313 & 0,4331 \\
\hline 2017 & 0,4866 & 0,3039 & 0,3925 & 0,4411 \\
\hline 2018 & 0,4196 & 0,2798 & 0,3686 & 0,4458 \\
\hline
\end{tabular}

In the last stage, the final index was developed by taking away the sub-index averages from 1 .

Table 3. Size and efficiency indexes

\begin{tabular}{lllllll}
\hline \multirow{2}{*}{ Years } & \multicolumn{2}{c}{ Size Index } & \multicolumn{3}{l}{ Efficiency Indexes } \\
\cline { 2 - 7 } & OECD & NON-OECD & Status * & OECD & NON-OECD & Status * \\
\hline 1995 & 0,6039 & 0,4804 & 1 & 0,6520 & 0,5906 & 1 \\
\hline 1996 & 0,5989 & 0,4880 & 1 & 0,6520 & 0,5906 & 1 \\
\hline 1997 & 0,6117 & 0,5016 & 1 & 0,6670 & 0,5751 & 1 \\
\hline 1998 & 0,6193 & 0,4676 & 1 & 0,7256 & 0,5354 & 1 \\
\hline 1999 & 0,6189 & 0,4412 & 1 & 0,7081 & 0,4981 & 1 \\
\hline 2000 & 0,6485 & 0,4617 & 1 & 0,6677 & 0,4868 & 1 \\
\hline 2001 & 0,6504 & 0,4706 & 1 & 0,6530 & 0,5357 & 1 \\
\hline 2003 & 0,6590 & 0,4482 & 1 & 0,6513 & 0,5951 & 1 \\
\hline 2004 & 0,6377 & 0,4141 & 1 & 0,6628 & 0,6037 & 1 \\
\hline 2005 & 0,6062 & 0,4656 & 1 & 0,6795 & 0,6588 & 1 \\
\hline 2006 & 0,6022 & 0,4423 & 1 & 0,6595 & 0,7237 & 0 \\
\hline
\end{tabular}




\begin{tabular}{lllllll}
\hline 2007 & 0,5981 & 0,4514 & 1 & 0,6484 & 0,6635 & 0 \\
\hline 2008 & 0,5943 & 0,5066 & 1 & 0,6365 & 0,6422 & 0 \\
\hline 2009 & 0,6113 & 0,4827 & 1 & 0,6365 & 0,6429 & 0 \\
\hline 2010 & 0,4938 & 0,4931 & 1 & 0,6458 & 0,6583 & 0 \\
\hline 2011 & 0,6136 & 0,4983 & 1 & 0,6040 & 0,6168 & 0 \\
\hline 2012 & 0,5897 & 0,4196 & 1 & 0,6061 & 0,6252 & 0 \\
\hline 2013 & 0,5297 & 0,5057 & 1 & 0,6125 & 0,6343 & 0 \\
\hline 2014 & 0,5737 & 0,4918 & 1 & 0,6451 & 0,5527 & 1 \\
\hline 2015 & 0,5485 & 0,4565 & 1 & 0,6457 & 0,5626 & 1 \\
\hline 2016 & 0,5284 & 0,5687 & 0 & 0,6856 & 0,5669 & 1 \\
\hline 2017 & 0,5134 & 0,6075 & 0 & 0,6961 & 0,5589 & 1 \\
\hline 2018 & 0,5804 & 0,6314 & 0 & 0,7202 & 0,5542 & 1 \\
\hline
\end{tabular}

*: "OECD >non-OECD = 1; OECD<non-OECD =0"

When Table 3 is examined, it can be seen that in only three of the 24 years included in the study $(2016,2017$, and 2018), the public sector size index value of the non-OECD countries was bigger than that of the OECD countries. As may be seen in Figure 2, while the volatility index of the size of the non-OECD countries is not high in the time period included in the study, their index value showed a significant increase in the last three years. On the other hand, it is seen that the index value of the OECD member countries indicated an increase from 1995 to 2003 and after 2003 showed a fluctuating tendency to decrease.

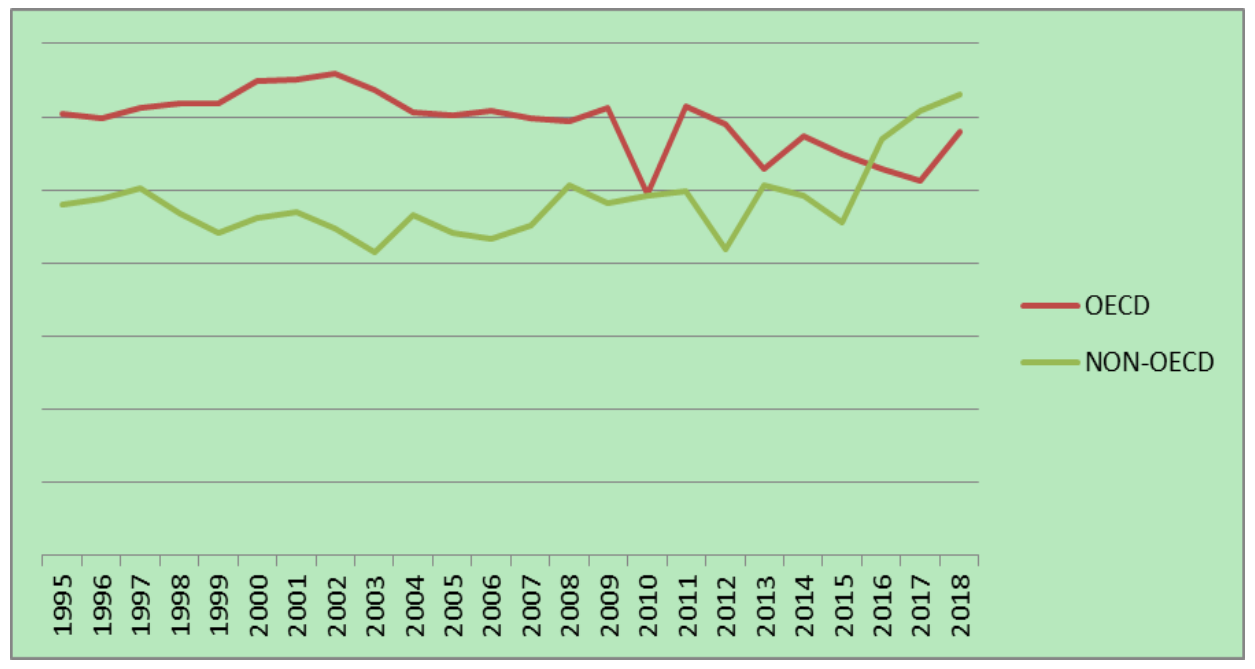

Figure 2. Comparison of size index value

When the index values are examined (Figure 3), it can be seen that in 15 out of the 24 years assessed, the public volume efficiency indexes of the OECD member countries have higher values than those of the non-OECD countries. When the change of index values of OECD member countries is examined, it is clear that they do not have extreme volatility, and their index value is approximately stable. However, in the non-OECD countries, efficiency had showed an increase from 2000 to 2006, but after 2006 the index value decreased. 


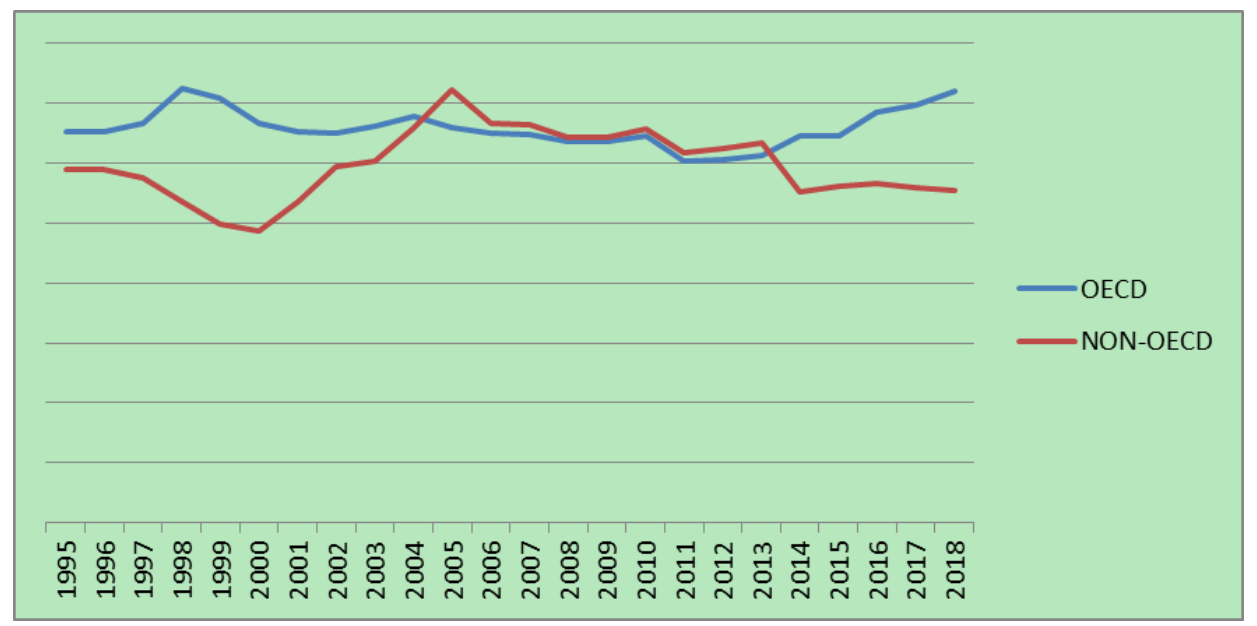

Figure 3. Comparison of efficiency index values

As may be seen in Table 3, in 12 out of the 24 years examined, both the public volume index and public efficiency index of OECD member countries are higher than non-OECD countries. When it is considered that OECD member countries included in the study are the ones with high levels of income, it could be seen that the public expenditures of those countries are far from populism and actually created to meet social needs.

In eight out of the 24 years examined, even though the size index value of the public volumes of non-OECD countries were lower than OECD member countries, their efficiency value was higher than that of the OECD member countries. In the period of 2005-2013, although the public volumes of non-OECD countries were lower than that of the OECD member countries, they were more efficient. This result can be evaluated, especially in Russia, India, China, and Brazil (BRICS countries). According to that, in the relevant period, the increase of India in the global competitiveness in parallel to its efficiency increase in production also accelerated growth. Even though the public expenditures remained at a limited level (27\%), the significant part of the present expenditures were transformed to efficient services by separating reform attempts of the government and investment programs from public support policies (McCartney, 2019). In the relevant period, the regulations realized by Russia in the banking sector strengthened the financial infrastructure. While the GDP rates increased, budget deficits decreased, and investment in the private sector increased. Although public expenditures are at a low level (33\%), efficiency is high (Becker, 2018). China is the world's largest manufacturing economy. It became a member of the World Trade Organization in 2001 and signed a free trade agreement with many countries. While expenditures in public finance were limited as a result of restructuring activities (23\%), the resources were transferred to efficient areas such as innovation, technology, the struggle against poverty, and environmental protection (deficit balancing procedure) (Sims, 2013). In the same period, Brazil cooperated with the IMF and made significant progress in terms of debts and budget deficits. The country debt to the IMF was paid in 2005. Brazil, the largest economy in South America, achieved restraint of its irregular public expenditures in that period $(38 \%)$ and could direct its public resources to the more efficient areas such as education, health, and social protection (Brew, 2018).

Although in three out of the 24 years examined, the public sector size index values of non-OECD member countries were higher than that of OECD member countries, their efficiency values were lower than the latter. Consequently, in the last three years, the public volumes of OECD member countries were more efficient than those of non-OECD countries, but lower.

\section{Conclusion}

When the data used in this study was examined, it could be seen that the growth in the public economy of the developed countries such as France, Finland, Denmark, Sweden, Norway, and Austria led to an increase in the efficiency of the public sector. In other words, the taxes collected from the citizens and the public goods and services produced transformed into public efficiency, that is, a social benefit which is twofold or more than itself. On the other hand, a significant part of underdeveloped countries, most of which are in Africa, and in developing countries, the growth in the public sector affected economic efficiency negatively, and public expenditures exceeded social benefit. For example, in the countries of Brazil and Russia, while the contribution of the growth in the public sector 
to efficiency remained limited, in the countries such as Mexico and Chile, the contribution of the public expenditures to economic efficiency was quite high.

Approaches related to political economy that determine the difference between efficiency and inefficiency are accepted important, from this point of view. Problems such as media restrictions, irregularities in public procurements, violations of regulations, the independence of the judiciary, unqualified civil servants, dysfunctionality of the state control mechanism, the existence of interest-based relationships in politics, and the level of the public's perception of corruption cause substantial social, economic, and political inefficiency. Additionally, the actual data on the global corruption index indicates that the corruption values of countries such as India, Brazil, and Russia are at the middle level while these values in China are at high at the national level. This situation shows that, in the countries and regions where democratic accountability is not at a sufficient level, public efficiency is also decreasing, and, even in the countries like Brazil and Algeria, this efficiency level has reached a negative level (Global Corruption Index, 2018; Nar, 2015c). To this point, when required, decreasing public expenditures, evaluating limited public resources, and increasing public expenditures for education and R \& D in terms of quality and quantity, and reaching higher production levels with the least input enable a redressing of the balance in the comparisons between expenditures and efficiency (Mandl et al, 2008).

On the other hand, the concept of global tax competition draws attention to the importance of discipline and compensation hypotheses in the determination of efficiency. Incidental but efficient expenditures, in particular, correspond to the hypothesis of discipline. Competing demand for foreign capital around the world prevents governments from placing a tax on capital. However, a decrease in the tax income limits the expenditure fields of the governments. Governments try to evaluate the present possibilities at hand in the best manner when cutting back on policies of public expenditures. As a result,, efficiency is created, and governments become disciplined. On the other hand, the hypothesis of compensation means that social expenditures will increase along with globalization. Particularly in developed countries, governments attach importance to the social state, understanding that it is necessary in order to provide security to their citizens against the risk of globalization. In this way, not only the negative effects of the globalization are eliminated, but also economic efficiency is provided (Avi-Yonah, 2001; Cnossen \& Smart, 2005; Dreher et al, 2008).

To conclude, in developed countries where the national level of income is high and the state has an important place in the economy, while the size of public sector grows, its efficiency level increases. Since an increase in the expenditures tends towards the production of the goods and services to which the society gives a priority, efficiency grows apace. On the other hand, in developing countries, since the growth in the public expenditures tends towards mostly public goods and services in which political actors are given priority, the efficiency either remains limited or is negative (Kaufmann et al., 2010; World Bank, 2018).

\section{References}

Avi-Yonah, R. S. (2001). Globalization and tax competition: Implications for developing countries. Cepal Review, 74(1), 59-66. https://doi.org/10.18356/7b6578e7-en

Bassam, A. (2020). A model for assessing the efficiency of government expenditure. Cogent Economics \& Finance, 8(1), 1-12. https://doi.org/10.1080/23322039.2020.1823065

Becker, T. (2018). The Russian economy under putin. Routledge. https://doi.org/10.4324/9780429504648

Bernholz, P., \& Vaubel, R. (2007). The effect of interjurisdictional competition on regulation: Theory and overview. In P. Bernholz, \& R. Vaubel (Eds.), Political competition and economic requlation. Routledge. https://doi.org/10.4324/9780203946879

Berry, W. D., \& Lowery, D. (1987). Understanding United States government growth. New York: Praeger.

Bilgili, Y. (2009). İktisat okulları: Makro iktisadın teorik esasları. Istanbul: Ikinci Sayfa Basım Yayın.

Brew, G. (2018). Gale researcher guide for: Emergence of the BRIC economies. GALE Cengage Company.

Brunori, D. (1998). The future of state Taxation. Rowman \& Littlefield Publishers.

Cnossen, S., \& Smart, M. (2005). Preliminaries. In S. Cnossen (Ed.), Theory and practice of excise taxation: Smoking, drinking, gambling, polluting, and driving. Oxford University Press.

Coniglione, F. (2013). Through the mirrors of science: New challenges for knowledge-based societies. Verlag.

Dewar, J. (2010). Financial scrutiny unit briefing: The size of the public sector. SPICe The İnformation Center.

Diamond, J. (1999). Guns, germs, and steel the fates of human societies. W. W. Norton. 
Dreher, A., Gaston, N., \& Martens, P. (2008). Measuring gflobalisation. New York: Springer-Verlag.

Dutu, R., \& Sicari, P. (2020). Public spending efficiency in the OECD: Benchmarking health care, education, and general administration. Review of Economic Perspectives, 20(3), 253-280. https://doi.org/10.2478/revecp-2020

Edizdoğan, N., Çetinkaya, Ö., \& Gümüş, E. (2012). Kamu maliyesi. Bursa: Ekin Yayıncılık.

Elias, N. (2002). Uygarlık süreci. Istanbul: Iletişim Yayınları.

Foster, K. A. (1997). The political economy of special-Purpose gvernment. Georgetown University Press.

Fourie, F. C., \& Burger, P. (2010). How to think and reason in macroeconomics. Publisher: Juta Academic.

Global Corruption Index. (2018). Ranking and scores. Retrieved from https://risk-indexes.com/global-corruption-index

Greiner, A., \& Fincke, B. (2009). Public debt and economic growth. Springer-Verlag Berlin Heidelberg. https://doi.org/10.1007/978-3-642-01745-2

Hallwood, P., \& MacDonald, R. (2009). The political economy of financing scottish government. Edward Elgar. https://doi.org/10.4337/9781848449183

Heer, B. (2019). Public economics: The macroeconomic perspective. Springer International Publishing.

Hindriks, J., \& Myles, G. D. (2006). Intermediate public economics. Cambridge, London: The MIT Press.

IMF. (1997). Good governance, the IMF's role. International Monetary Fund Publication Services. Washington DC.

Kalenderoğlu, M. (2013). Kamu maliyesi bütçe ve borçlanma. Ankara: Agon Yayıncılık.

Kaufmann, D., Kraay, A., \& Mastruzz1, M. (2010). The world wide governance indicators: Methodology and analytical 1ssues. Research Working Paper, World Bank Policy Research.

Kosor, M., Perovic, L., \& Golem, S. (2019). Efficiency of public spending on higher educatıon: A data envelopment analysis for EU-28. Problems of Education in the 21st Century, 77(3), 396-409.

Kwon, H. (1999). The welfare state in Korea: The politics of legitimization. Palgrave Macmillan UK. https://doi.org/10.1057/9780230374294

Mandl, U., Dierx, A., \& Ilzkovitz, F. (2008). The effectiveness and efficiency of public spending. Economic Papers 301. Brussels: European Commission.

McCartney, M. (2019). The Indian Economy. Agenda Publishing. https://doi.org/10.2307/j.ctvnjbfk1

Musgrave, R. A. (2000). Public finance in a democratic society: The foundations of taxation and expenditure. Edward Elgar.

Musgrave, R. A. (2006). Public finance and the three branch model. In A. Ott, \& R. Cebula (Eds.), Empiricial public Economics. Edward Elgar.

Musgrave, R. A., \& Musgrave, P. B. (2017). Public Finance in Theory and Practice. Tata McGraw-Hill.

Nar, M. (2013). Kamu ekonomisi, ekonomik etkinlik ve vergileme. Seçkin yayıncılık.

Nar, M. (2015). The committed changes within public procurement law in Turkey (2003-2014). International Journal of Business and Social Research, 5(2), 1-20.

Nar, M., \& Nar, M. Ş. (2019). An updated assessment of the OECD's quality of life index. Problemy EkorozwojuProblems of Sustainable Development, 14(1), 7-18.

Neuberger, E. (1971). Classifying economic systems. In A. Brown, E. Neuberger, \& M. Palmatier (Eds.), Perspectives in economics. New York: McGraw Hill.

O’Neill, J. (2001). Piyasa: etik bilgi ve politika. Istanbul: Ayrıntı Yayınları.

OECD. (2012). Economic policy reforms: Going for growth. OECD Publishing.

Öztürk, N. (2020). Maliye politikası. Ekin Yayıncılık.

Piketty, T. (2015). The economics of inequality. Harvard University Press. https://doi. org/10.4159/9780674915565

Screpanti, E., \& Zamagni, S. (2005). An outline of the history of economic thought. Oxford University Press. https://doi.org/10.1093/0199279144.001.0001

Sen, A. (1997). Ineguality unemployment and contemporary Europe. International Labour Review, 136(2), $155-171$. 
Shughart, W. (2004). Regulation and antitrust. In C. Rowley, \& F. Schneider (Eds.), The encyclopedia of public choice. Kluwer Academic Press. https://doi.org/10.1007/978-0-306-47828-4_22

Sims, D. (2013). China widens lead as world's largest manufacturer. Retrieved from: thomasnet.com.

Wentzel, J. (2011). An imperative to adjust? Skill formation in England and Germany. Publisher: VS Research. https://doi.org/10.1007/978-3-531-92797-8

WGI. (2020). Worldwide governance indicators (WGI) project. Retrieved from https://info.worldbank.org/governance/wgi/

World Bank. (2018). The worldwide governance indicators: Methodology and analytical issues. The World Bank.

\section{Copyrights}

Copyright for this article is retained by the author(s), with first publication rights granted to the journal.

This is an open-access article distributed under the terms and conditions of the Creative Commons Attribution license (http://creativecommons.org/licenses/by/4.0/). 